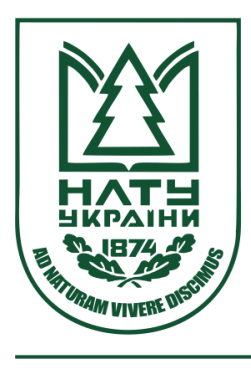

Науковий вісник НлтУ України Scientific Bulletin of UNFU

http://nv.nltu.edu.ua

https://doi.org/10.15421/40290704

$@ \bowtie$ Correspondence author

Article received 30.08.2019 p.

Article accepted 26.09.2019 p.

V. Yu.Yukhnovskyi

Удк 331.14:502.171(477.41-21)

yukhnov@ukr.net

О. В. Зібцева, В. Ю. Юхновський

Наџіональний університет біоресурсів і природокористування України, м. Київ. Україна

\title{
ВАРТІСТЬ ВІДНОВЛЕННЯ ЕКОСИСТЕМ МАЛИХ МІСТ КИЇВЩИНИ ЯК ПОКАЗНИК ЕКОЗБАЛАНСОВАНОСТІ
}

\begin{abstract}
Проаналізовано динаміку структури територій малих міст Київщини та визначено екозбалансованість територій шляхом порівняльного аналізу міст за вартістю відновлення їх екосистем. Вартість екостабілізувальних біотопів на 1 га міської площі розраховано для попереднього стану кожного міста і на 20-річну перспективу. Виявлено, що зростання площі відбувалося у 72 \% малих міст із розширюванням їх забудови. Найвищим рівнем забудови характеризуються міста Вишневе, Переяслав-Хмельницький, Васильків, Фастів, а найменшим - Кагарлик і Яготин. Значна частка в загальній площі міських біотопів належить присадибним садам, питома вага яких змінюється в межах від 4 до $30 \%$. Орні землі представлені вкрай нерівномірно і в деяких містах відсутні, хоча їхня частка в окремих містах сягала $80 \%$, а в перспективних планах - $50 \%$. Ліси відсутні на території третини дослідних міст. Площа водних поверхонь найістотніше позначається на вартості біотопів, характеризується нерівномірним розподілом і її частка сягає 30 \%. Здебільшого присадибні сади займають найбільшу питому вагу в загальній вартості міських біотопів. В окремих випадках їм належить до 85 \% вартості. Найбільший відсоток лісів у загальній вартості відзначено для міст Ржищів, Вишгород, Ірпінь, а водойм - для міст Яготина, Тетієва, Миронівки, Богуслава, Кагарлика. Ці показники важливо враховувати у перспективних планах розвитку міст, де для обгрунтування нормативної площі зелених просторів потрібно брати не тільки рекреаційні норми зелених насаджень загального користування, а сукупність екосистемних послуг багатофункціональних зелених територій, які гарантуватимуть екозбалансований розвиток тери-
\end{abstract} торій.

Ключові слова: екосистемні послуги; зелені насадження; біотоп; генеральний план міста.

Вступ. Глобальна урбанізація є серйозним викликом сталому розвитку та ефективному міському управлінню. Швидкі зміни у використанні міських земель завдають серйозної шкоди глобальному екологічному середовищу та екосистемним послугам (Xu et al., 2019). Плани землекористування часто використовують для управління містобудівним розвитком, що може вплинути на різноманітність і просторовий розподіл міських екосистемних послуг (Lam \& Conway, 2018). Оскільки зменшення екостабілізуючих угідь призводить до втрат зеленого простору міста, оптимізація землекористування $€$ ефективним інструментом раціоналізації його структури з метою забезпечення очікуваних екосистемних послуг (Wang et al., 2018).

Планування сучасного міста передбачає забезпечення якісного навколишнього середовища, зокрема зелену інфраструктуру для сталого міського розвитку (Olic \& Stober, 2019). Оцінювання екосистемних послуг у містах та інтеграція природних цінностей у прийняття рішень приводить до значного позитивного впливу на навколишнє середовище та якість життя. Водночас теоретичне підгрунтя міських екосистемних послуг менш $€$ визначено, ніж сільських або лісових (Bastian et al.,
2012). Потенційне забезпечення регулювальних екосистемних послуг просторово обмежено типами землекористування (Arnold et al., 2018). Які саме екосистемні послуги у відповідному місті є найбільш актуальними, залежить від його екологічних та соціально-економічних характеристик (Gómez-Baggethun \& Barton, 2013).

Вкрай необхідним $є$ розроблення превентивних заходів щодо запобігання та зниження негативних впливів на навколишнє середовище (May \& Spirin, 2014). На сучасному етапі відбувається розширення оцінкового підходу: відмова від фрагментарної оцінки і перехід до комплексної, суцільної інвентаризації та оцінювання компонентів і видів користування на всіх рівнях територіального планування, перехід від галузевого й об'єктного підходу до комплексного врахування екологічних вимог. Тому виникає необхідність підкріпити обов'язкові до застосування інструктивні та методичні документи на підзаконній основі. Збереження біорізноманіття та екосистемних послуг потребує застосування широкого спектра законодавчих, політичних, економічних і соціальних інструментів (Artmann et al., 2017).

Розроблення стратегії сталого регіонального розвитку та оптимізації природокористування передбачає не-

\section{Інформація про авторів:}

Зібцева Ольга Василівна, канд. с.-г. наук, доцент, кафедра ландшафтної архітектури та садово-паркового будівництва. Email: stplut2017@gmail.com; https://orcid.org/0000-0003-0706-0738

Юхновський Василь Юрійович, д-р с.-г. наук, професор, кафедра відтворення лісів та лісових меліорацій. Email: yukhnov@ukr.net; http://orcid.org/0000-0003-3182-4347

Цитування за ДСтУ: Зібцева О. В., Юхновський В. Ю. Вартість відновлення екосистем малих міст Київщини як показник екозбалансованості. Науковий вісник НЛтУ України. 2019, т. 29, № 7. С. 21-26.

Citation APA: Zibtseva, O. V., \& Yukhnovskyi, V. Yu. (2019). The Restoration Cost of the Ecosystems of Small Towns of Kyiv Region as an Index of Eco-Balance. Scientific Bulletin of UNFU, 29(7), 21-26. https://doi.org/10.15421/40290704 
обхідність оцінювання природно-ресурсного потенціалу, екологічних і соціально-економічних умов території для коректного вибору напрямів і заходів оптимізації землекористування (Semenov, 2014). Одним 3 інструментів такого планування $є$ ландшафтне планування ієрархічна система, де планувальні приписи різних рівнів доповнюють один одного за принципом "обліку суперечностей", завдяки чому на кожному рівні ієрархії ландшафтних планів вирішуються різні завдання щодо виявлення і диференціації екосистемних послуг.

Збільшення використання природи в економічних цілях призводить до зменшення іiї регулювальних і соціально-культурних послуг. Завдання концепції ЕП полягає в інтерпретації взаємозалежностей і властивостей, функцій і послуг екосистем у їх територіальній і часовій диференціаціях. Особливі виклики щодо ЕП пов'язані з недостатнім розвитком методологічних підходів, що відповідають умовам країни. Німеччина $\epsilon$ одним з ініціаторів міжнародного дослідницького процесу TEEB (The Economics of Ecosystem Services and Biodiversity) i активним учасником проекту IPBES (Intergovernmental Science-Policy Platform on Biodiversity and Ecosystem Services). Однак, навіть у Німеччині немає грунтовних інтегрованих знань про стан і розвиток ЕП у плані національної економічної оцінки (Yukhnovskyi \& Zibtseva, 2019).

Наразі сформувалися різні теоретичні підходи i практичні методи, які доповнюють один одного (Bastian et al., 2015). Концепція визначення повної вартості екосистемних послуг міських територій $\epsilon$ однією 3 найбільш популярних. Методи непрямого ринкового оцінювання охоплюють визначення запобіжних витрат, альтернативної вартості тощо. Підходи на підставі витрат враховують витрати, пов'язані з наданням екологічних товарів і послуг. Метод вартості заміни або відновлення пошкодженого активу до його початкового стану часто використовують завдяки легкості оцінки таких витрат. Різновиди оцінювання обирають 3 огляду на особливості та цілі дослідження (Groot et al., 2002). На думку (Grunewald et al., 2014), зважаючи на поставлену Європейським Союзом мету припинення втрат біорізноманіття, екзистенційні цінності біотопів, що мають особливе значення для збереження біорізноманіття, можна розраховувати на підставі витрат на відновлення, враховуючи необхідний для відновлення час. Наприклад, у межах визначення виплат на відшкодування шкоди за методом Habitat-Equivalency (Semenov, 2014).

Мета дослідження - відстежити динаміку структури міських територій та екозбалансованості малих міст Київської обл. за відновлювальною вартістю екосистем на їх територіях та оцінити досконалість запланованої структури землекористувань у перспективних планах міст з огляду на їх стабільний екозбалансований розвиток.

Матеріали і методика дослідження. Об'єктом дослідження обрано найпоширенішу категорію українських міст - малі міста (з населенням від 10 до 50 тис. жителів) Київської обл., на яку припадає 80 \% від загальної кількості міст (рис. 1).

Нашими попередніми дослідженнями виявлено, що кількість населення у малих містах області достовірно негативно корелює із відстанню до Києва, у зоні впливу якого ці міста перебувають. Для 20 міст області встановлено значну тісноту зв'язку між цими показниками, про що свідчить коефіцієнт кореляції $r=-0,63^{ \pm 0,135}$ $(t=3,43, P=0,99)$.

Аналіз територіальної структури проведено на базі основних показників наявних генеральних планів малих міст, наданих ДП "Український державний науково-дослідний інститут проектування міст "ДІПРОМІСТО" ім. Ю. М. Білоконя".

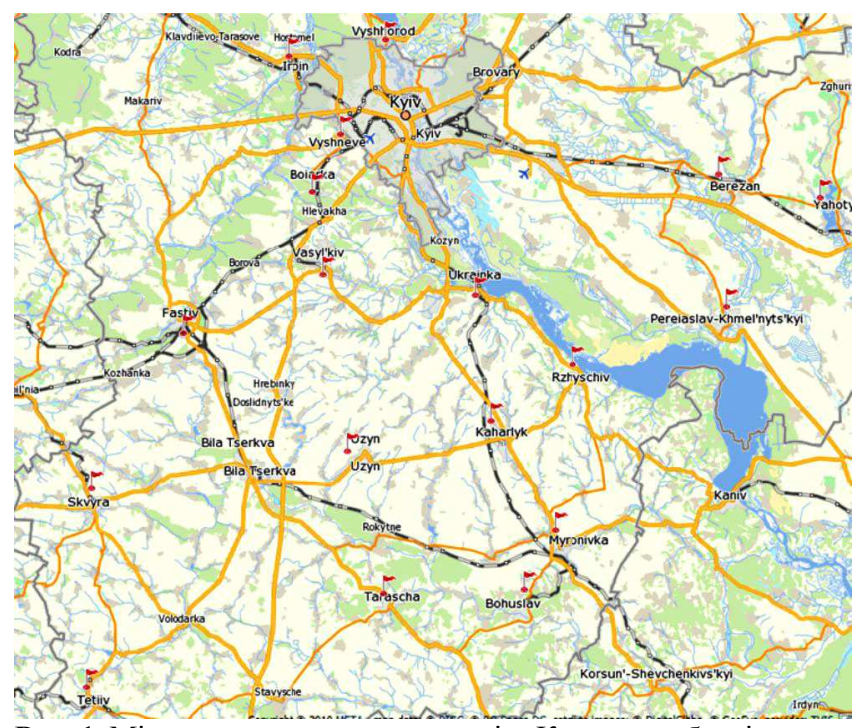

Рис. 1. Місце розташування малих міст Київської обл. відносно м. Києва

Високий антропоекологічний ризик і низький екологічний потенціал характерні для території міст, розташованих вздовж Дніпра (Київського водосховища): Вишгород, Українка, Ржищів. Для більшості малих міст характерний середній еколого-економічний потенціал території і помірні екологічні обмеження виробництва, шкідливого для навколишнього середовища і населення. Найнижче техногенне навантаження на природне середовище характерне для міст більш віддалених від Києва - Тетіїв, Сквира, Березань.

Міський метаболізм розглядає місто як систему, в межах якої можна оцінити рух ресурсів (Choe \& Thorne, 2019). Використано підхід міського метаболізму для оцінювання динаміки структури міських територій i вартості міських екосистем.

3 огляду на обмеженість даних для оцінювання i трудомісткість робіт, ми застосували метод трансферу цінності, який використовують у разі повної відсутності інформації (кошт або часу) для оцінювання екосистемних послуг. Для визначення вартості всіх екосистемних послуг на території міст використали методику, яка враховує важливі для збереження біорізноманіття типи екосистем та вартість одиниці площі кожного 3 них (Schweppe-Kraft, 2014). Таким чином розраховували вартість відшкодування збитку для різних типів біотопів аналогічно методу "Habitat-EquivalencyAnaslysis" з урахуванням усереднених відновлювальних витрат і тривалості відновлення. Застосували оцінку типів біотопів Німеччини, скориговану до умов України використанням коефіцієнта переносу вартості. За даними Світового банку на 2014 р., ВВП за паритетом постійної купівельної спроможності на особу населення для Німеччини становив 45615 дол., а для України 8790 дол., тобто коефіцієнт переносу вартості становив 0,19. Скориговані значення вартості ми навели у табл. 1, у якій міські незабудовані землі розподілили на сім типів біотопу. 
Табл. 1. Скоригована вартість відшкодування збитку для різних типів біотопів

\begin{tabular}{|c|l|cc|c|}
\hline \multirow{2}{*}{$\begin{array}{r}\text { № } \\
\text { 3/п }\end{array}$} & \multicolumn{1}{|c|}{ Тип біотопу } & \multicolumn{3}{|c|}{ Вартість } \\
\cline { 3 - 5 } & $\begin{array}{c}\text { ввро/ } \\
\mathbf{M}^{2}\end{array}$ & $\begin{array}{c}\text { тис. } \\
\text { дол./га }\end{array}$ & $\begin{array}{c}\text { тис. } \\
\text { дол./га* }\end{array}$ \\
\hline 1 & Суходольні й екстенсивні луки & 8,06 & 90,27 & 17,15 \\
\hline 2 & Низинні болота & 9,80 & 109,76 & 20,85 \\
\hline 3 & Екстенсивні орні поля & 0,49 & 5,49 & 1,04 \\
\hline 4 & $\begin{array}{l}\text { Луки черезсмужного плодівниц- } \\
\text { тва }\end{array}$ & 9,75 & 109,20 & 20,75 \\
\hline 5 & $\begin{array}{l}\text { Живоплоти, чагарники, переліс- } \\
\text { ки** }\end{array}$ & 16,28 & 182,34 & 34,64 \\
\hline 6 & Природні й екоорієнтовані ліси & 18,44 & 206,53 & 39,24 \\
\hline 7 & $\begin{array}{l}\text { Екоорієнтовані заводі та проточ- } \\
\text { ні води }\end{array}$ & 48,93 & 548,02 & 104,12 \\
\hline
\end{tabular}

Примітка: * - враховано коефіцієнт переносу вартості $(\times 0,19)$;

** - до категорії увійшли зелені насадження загального користування і спецпризначення.

До п'ятого типу біотопу віднесли зелені насадження загального користування та спеціального призначення, зокрема: кладовища, території санітарно-захисних зон, смуг відведення залізниць і ліній електропередач. До четвертого типу біотопу віднесли розсадники і половину площ садиб, а до п'ятого - городи і сільськогосподарські підприємства. Таким чином, максимальну одиничну вартість мають водні об'єкти, що в 2,6 раза перевищує вартість одиниці площі лісів і майже у 100 разів - вартість орних полів. У підсумку, це істотно позначається на сумарній вартості біотопів у межах міських територій. Подальший аналіз охоплював перерахунок вартості на 1 га площі міської території.

Результати дослідження та їх обговорення. У табл. 2 навели площі малих міст та розподіл їх територій за типами біотопів на підставі показників генерального планування різних років (починаючи від 1964 р. для Обухова до 2016 р. для Вишневого) як за існуючою ситуацією, так і за відповідно запланованою 20-річною перспективою. Тут і далі в дужках подали заплановані перспективні показники (роки досягнення планових показників).

Табл. 2. Розподіл площ малих міст за типами біотопів

\begin{tabular}{|c|c|c|c|c|c|c|c|c|c|}
\hline \multirow{2}{*}{ Місто } & \multirow{2}{*}{ Рік } & \multicolumn{7}{|c|}{ Тип біотопу, га } & \multirow{2}{*}{$\begin{array}{c}\text { Площа } \\
\text { міста, га }\end{array}$} \\
\hline & & 1 & 2 & 3 & 4 & 5 & 6 & 7 & \\
\hline \multirow{2}{*}{ Березань } & 2008 & 34,7 & $\overline{75,2}$ & 231,5 & 390,25 & 39,5 & & 12,4 & 1545,0 \\
\hline & 1978 & 12,8 & & 190,4 & 247,95 & 96,1 & & 22,4 & 1520,4 \\
\hline \multirow{2}{*}{ Богуслав } & 1983 & & & 165,0 & 180,5 & 19,5 & 49,0 & 39,0 & 1005,0 \\
\hline & 2003 & & & 157,0 & 185,5 & 78,8 & 49,0 & 39,0 & 1005,0 \\
\hline \multirow{2}{*}{ Боярка } & 2008 & & & 12,3 & 340,3 & 100,1 & 29,8 & 10,9 & 1122,0 \\
\hline & 2028 & & & & 411,05 & 134,9 & 1726 & 10,9 & 3389,0 \\
\hline \multirow{2}{*}{ Буча } & 2012 & & & 476,0 & 358,0 & 186,4 & 42,6 & 40,1 & 2658,1 \\
\hline & 2032 & & & & 460,3 & 489,6 & 6,0 & 40,1 & 2658,1 \\
\hline \multirow{2}{*}{ Васильків } & 2015 & & 43,5 & 468,8 & 446,0 & 17,0 & 68,9 & 39,0 & 2248,0 \\
\hline & 2035 & & & 161,0 & 570,4 & 836,0 & 14,7 & 41,4 & 3000,0 \\
\hline \multirow{2}{*}{ Вишгород } & 1990 & & & & 56,2 & 201,0 & & 9,6 & 629,5 \\
\hline & 2010 & & & 44,5 & 82,8 & 183,7 & 85,2 & 2,3 & 873,7 \\
\hline \multirow{2}{*}{ Вишгород } & 1970 & & & & 87,55 & 3,0 & & 2,0 & 504,8 \\
\hline & 1990 & & & 26,5 & 56,85 & 51,2 & 121,0 & 2,3 & 525,3 \\
\hline \multirow{2}{*}{ Вишневе } & 2016 & & & & 33,5 & 64,8 & & 0,5 & 704,1 \\
\hline & 2036 & & & & 48,5 & 153,0 & & 2,0 & 1151,0 \\
\hline \multirow{2}{*}{ Ірпінь } & 2010 & & & 612,6 & 362,1 & 156,0 & 964,0 & 120,4 & 3705,1 \\
\hline & 2031 & 364 & & 35,6 & 454,9 & 805,0 & 206,0 & 52,0 & 3705,1 \\
\hline \multirow{2}{*}{ Кагарлик } & 2013 & & 74,5 & 1087,0 & 153,1 & 100,8 & 136,4 & 87,6 & 2130,7 \\
\hline & 2033 & & & 865,7 & 223,75 & 285,3 & 76,9 & 87,6 & 2280,0 \\
\hline \multirow{2}{*}{ Миронівка } & 1981 & 40 & & 61,0 & 172,5 & 44,0 & & 90,0 & 917,0 \\
\hline & 2001 & 34 & & 45,0 & 160,25 & 126,0 & & 90,0 & 922,0 \\
\hline \multirow{2}{*}{ Обухів } & 1964 & & 180,0 & 209,1 & 250,0 & 12,9 & 30,1 & 11,0 & 1124,6 \\
\hline & 1984 & & 84,3 & 176,7 & 177,95 & 108,2 & 68,5 & 22,5 & 2196,7 \\
\hline \multirow{2}{*}{$\begin{array}{c}\text { Переяслав- } \\
\text { Хмельницький }\end{array}$} & 2007 & 112 & & 600,4 & 798,15 & 35,8 & 15,5 & 66,7 & 3152,0 \\
\hline & 2027 & 252 & & & 853,15 & 214,1 & & 124,7 & 3152,0 \\
\hline \multirow[b]{2}{*}{ Ржищів } & 1992 & & 1414,0 & 178,1 & 374,6 & 3,3 & 210,0 & & 2168,0 \\
\hline & 2012 & & 1126,0 & 263,8 & 586,3 & 17,7 & 210,0 & & 2173,0 \\
\hline \multirow{2}{*}{ Сквира } & 1980 & 41,7 & & 211,4 & 409,55 & 17,0 & & 53,4 & 1485,0 \\
\hline & 2000 & 46,7 & & & 361,05 & 88,9 & & 57,0 & 1573,0 \\
\hline \multirow{2}{*}{ Тетіїв } & 1993 & 12 & & 34,72 & 165,0 & 34,57 & & 184,9 & 1440,0 \\
\hline & 2013 & & & 23,9 & 221,0 & 254,2 & & 140,5 & 1800,7 \\
\hline \multirow{2}{*}{ Узин } & 1966 & & 4,2 & 209,3 & 307,1 & 17,3 & 8,7 & 49,9 & 1224,6 \\
\hline & 1986 & & - & 184,2 & 254,8 & 103,8 & 13,4 & 52,8 & 1249,1 \\
\hline \multirow{2}{*}{ Фастів } & 2014 & & 18,8 & 147,0 & 767,85 & 68,7 & 52,5 & 237,0 & 4070,0 \\
\hline & 2035 & & & 1019,0 & 690,43 & 317,9 & 14,02 & 85,0 & 4562,5 \\
\hline \multirow{2}{*}{ Фастів } & 1994 & & 159,0 & 1797,0 & 668,0 & 207,8 & 56,0 & 85,0 & 2513,0 \\
\hline & 2015 & & & 1199,0 & 633,33 & 185,0 & 14,02 & 85,0 & 4386,0 \\
\hline Яготин & 2009 & & 409,8 & 1316,0 & 510,75 & 215,8 & 74,0 & 1641,0 & 5840,0 \\
\hline & 2031 & & 240,7 & 121,3 & 657,35 & 834,4 & 74,0 & 1805,2 & 5957,0 \\
\hline
\end{tabular}

Міста - динамічні системи, площа яких зазвичай постійно розширюється. За наявними даними, найбільший приріст території з часом відбувся в Обухові- в 2,2 раза (від 1124,6 до 2419 га), Фастові - в 1,7 раза (від 2513 до 4386), а також втричі у Боярці (від 1122 до 3389 га). Генеральним планом тільки для Березані передбачено зменшення території міста на 24,6 га, хоча наразі площа міста зросла у 2,1 раза і становить 3292 га. Стабільною залишилася площа Бучі, Ірпеня, Богуслава, але 31983 р. і понині площа Богуслава зросла в 1,6 раза (від 1005 до 1590 га). Площа Переяслав-Хмельницького була незмінною, але 32007 р. вже зросла на 48 га (від 3152 до 3200 га). 
У 13 з розглянутих 18 (72\% загальної кількості малих міст) прикладів передбачено зростання міської площі, причому найбільшою мірою за генеральними планами міст Фастова, Боярки, Обухова, Василькова. Паралельно з розширенням площі міст, збільшувалися їх забудовані території (рис. 2), максимальні значення яких наразі характерні для Вишневого (85,9 \% зараз і 86,5 \% на перспективу, що $\epsilon$, безумовно, занадто високим показником), Переяслава (78,3 і 96,0% відповідно і такий запланований показник важко пояснити розумно), Березані (74,5 і 70,3 \%). Натомість найнижчі рівні забудови міської території спостерігали у Ржищеві у 1992 р. (менше $20 \%$ ), наразі в Кагарлику - до $30 \%$, Яготині до $40 \%$, що зумовлено $28 \%$ водойм.

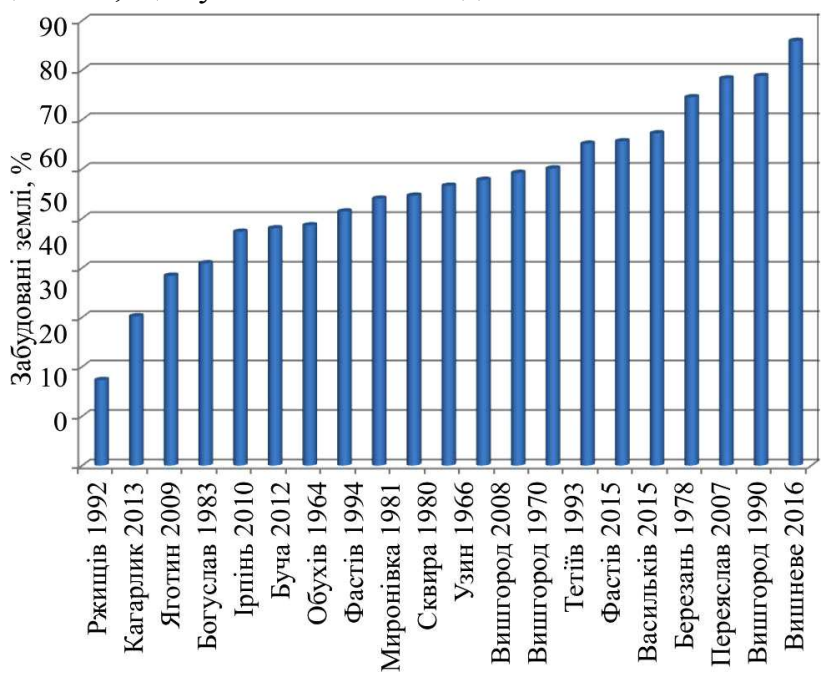

Рис. 2. Міста в порядку зростання відсотка забудови на їх територіях у різні роки

У структурі міської території серед біотопів усіх міст представлені, інколи з переважаючою участю, сади садиб, площа яких в абсолютному значенні змінюється від 33,5 га (4,8 \%) у Вишневому, до 798 га (27,1\%) у Переяславі та 30,3\% у Боярці, Значну питому вагу займають насадження загального користування і спецпризначення, площа яких змінюється від 3 га на початковому етапі у Вишгороді і до 834 га на заплановану перспективу в Яготині (або в межах від 0,2 до 9,7\%). Для цілей генерального планування прямо нормуються тільки зелені насадження загального користування з огляду тільки на їхню рекреаційну функцію. Вони мають відносно невелику частку участі - не більше $10 \%$. Ліси відсутні в шести малих містах і в семи перспективних планах, луки трапляються тільки в п'яти, а болота - у семи містах. За перспективним плануванням вони залишаться тільки в трьох містах. Оранки відсутні тільки в трьох містах, а в перспективі їх не буде вже в п'яти. Надзвичайно великий розмах у площі водних поверхонь: від 0,5 га у Вишневому до 1640,7 га в Яготині із перспективним збільшенням до 1805,2 га (або від 0,1 до 30,3 \% міської території відповідно). Усе це призведе до зменшення екозбалансованості дослідних міст.

За розглянутий період було заплановано стабільний розвиток або покращення міської структури тільки у чотирьох містах: Узині, Богуславі, Миронівці, Вишгороді. Натомість інтенсивний розвиток Обухова за планом передбачав кардинальне (у 2,1 раза) скорочення сумарної відсоткової площі біотопів. Аналогічно, істотне скорочення площ біотопів планували перспективним розвитком Березані (на 35 \%) і Сквири (на 40 \%), завдяки якому зазвичай, розширювалася міська забудова.

Подальше зниження загальної території під біотопами передбачено генеральними планами Яготина, Ірпеня, Переяслава, Фастова і Бучі. Натомість для Василькова, Боярки, Вишневого заплановане збільшення площ біотопів, що є позитивним явищем. На перспективу не передбачено скорочення відсоткової площі екостабілізуючих угідь у Кагарлику, Василькові, Боярці й Вишневому, тобто тільки у 40 \% малих міст, що мають актуальні генеральні плани. Відповідно до запланованих показників, ситуація погіршиться в Бучі та вони зменшаться нижче критичних, тобто регламентованих нормами, $40 \%$ території.

Загалом зміна біотопів має різноплановий характер і залежить від адміністративних рішень. Зокрема поява i динаміка площі лісів зумовлені розширенням міських меж і включенням до складу міської території приміських лісових масивів, а також їх забудовою.

У табл. 3 навели загальну вартість біотопів міст на час генерального планування і перспективу, а на рис. 3 - динаміку вартості екосистемних послуг (вартість екостабілізуючих біотопів) у розрахунку на 1 га міської території кожного міста за генеральними планами різних періодів (1960-1970-х, 1980-1990-х років та сучасними планами).

Табл. 3. Вартість екосистемних послуг малих міст (за Schweppe-Kraft, 2014)

\begin{tabular}{|c|c|c|c|c|c|c|c|c|c|}
\hline \multirow{2}{*}{ Місто } & \multirow{2}{*}{ Рік } & \multicolumn{7}{|c|}{ Вартість типу біотопу, тис. дол. } & \multirow{2}{*}{$\begin{array}{c}\text { Загальна вартість, } \\
\text { тис. дол. }\end{array}$} \\
\hline & & 1 & 2 & 3 & 4 & 5 & 6 & 7 & \\
\hline 1 & 2 & 3 & 4 & 5 & 6 & 7 & 8 & 9 & 10 \\
\hline \multirow{2}{*}{ Березань } & 1978 & 595 & 1568 & 241 & 8098 & 1368 & - & 1291 & 13161 \\
\hline & 2008 & 219 & - & 198 & 5145 & 3329 & - & 2332 & 11224 \\
\hline \multirow{2}{*}{ Богуслав } & 1983 & - & - & 173 & 3745 & 675 & 1923 & 4061 & 10576 \\
\hline & 2003 & - & - & 163 & 3849 & 2730 & 1923 & 4061 & 12725 \\
\hline \multirow[b]{2}{*}{ Боярка } & 2008 & - & - & 13 & 7061 & 3467 & 1169 & 1135 & 12846 \\
\hline & 2028 & - & - & & 8529 & 4673 & 67760 & 1135 & 82097 \\
\hline \multirow{2}{*}{ Буча } & 2012 & - & - & 495 & 7429 & 6457 & 1672 & 4175 & 20227 \\
\hline & 2032 & - & - & & 9551 & 16960 & 235 & 4175 & 30922 \\
\hline \multirow{2}{*}{ Васильків } & 2015 & - & 907 & 488 & 9254 & 589 & 2704 & 4061 & 18002 \\
\hline & 2035 & - & - & 167 & 11836 & 28959 & 577 & 4311 & 45850 \\
\hline \multirow{2}{*}{ Вишгород } & 1990 & - & - & - & 1166 & 6963 & - & 1000 & 9128 \\
\hline & 2010 & - & - & 5 & 197 & 727 & 385 & 31 & 1346 \\
\hline \multirow{2}{*}{ Вишгород } & 1970 & - & - & - & 1817 & 104 & - & 208 & 2129 \\
\hline & 1990 & - & - & 333 & 1180 & 1774 & 4748 & 239 & 8273 \\
\hline \multirow{2}{*}{ Вишневе } & 2016 & - & - & - & 695 & 1205 & - & 52 & 1953 \\
\hline & 2036 & - & - & - & 1006 & 5300 & - & 208 & 6515 \\
\hline Ірпінь & 2010 & - & - & 637 & 7514 & 5404 & 37827 & 12536 & 63918 \\
\hline
\end{tabular}




\begin{tabular}{|c|c|c|c|c|c|c|c|c|c|}
\hline 1 & 2 & 3 & 4 & 5 & 6 & 7 & 8 & 9 & 10 \\
\hline & 2031 & 6242 & - & 37 & 9439 & 27885 & 8083 & 5414 & 57101 \\
\hline \multirow{2}{*}{ Кагарлик } & 2013 & - & 1553 & 1131 & 3177 & 3492 & 5352 & 9121 & 23826 \\
\hline & 2033 & - & - & 900 & 4643 & 9883 & 3018 & 9121 & 27564 \\
\hline \multirow{2}{*}{ Миронівка } & 1981 & 686 & - & 63 & 3579 & 1524 & - & 9371 & 15224 \\
\hline & 2001 & 583 & - & 47 & 3325 & 4365 & - & 9371 & 17691 \\
\hline \multirow{2}{*}{ Обухів } & 1964 & - & 3753 & 217 & 5188 & 447 & 1181 & 1145 & 11931 \\
\hline & 1984 & - & 1758 & 184 & 3692 & 3748 & 2688 & 2343 & 14413 \\
\hline \multirow{2}{*}{$\begin{array}{c}\text { Переяслав- } \\
\text { Хмельницький }\end{array}$} & 2007 & 1917 & - & 624 & 16562 & 1240 & 608 & 6945 & 27896 \\
\hline & 2027 & 4322 & - & - & 17703 & 7416 & - & 12984 & 42425 \\
\hline \multirow{2}{*}{ Ржищів } & 1992 & - & - & 1471 & 3695 & 114 & 8240 & - & 13520 \\
\hline & 2012 & - & - & 1172 & 5474 & 613 & 8240 & - & 15499 \\
\hline \multirow{2}{*}{ Сквира } & 1980 & 715 & - & 220 & 8498 & 589 & - & 5560 & 15582 \\
\hline & 2000 & 801 & - & & 7492 & 3080 & - & 5935 & 17307 \\
\hline \multirow[b]{2}{*}{ Тетіїв } & 1993 & 206 & - & 36 & 3424 & 1198 & - & 19253 & 24116 \\
\hline & 2013 & - & - & 25 & 4586 & 8806 & - & 14629 & 28046 \\
\hline \multirow{2}{*}{ Узин } & 1966 & - & 88 & 218 & 6372 & 599 & 341 & 5196 & 12814 \\
\hline & 1986 & - & - & 192 & 5287 & 3596 & 526 & 5498 & 15098 \\
\hline \multirow{2}{*}{ Фастів } & 2014 & - & 392 & 153 & 15933 & 2380 & 2060 & 24676 & 45594 \\
\hline & 2035 & - & - & 1060 & 14326 & 11015 & 550 & 8850 & 35802 \\
\hline \multirow{2}{*}{ Фастів } & 1994 & - & 33155 & 20909 & 13861 & 7198 & 2197 & 8850 & 37512 \\
\hline & 2015 & - & - & 1247 & 13142 & 6408 & 550 & 8850 & 30198 \\
\hline \multirow{2}{*}{ Яготин } & 2009 & - & 5019 & 126 & 13640 & 28906 & 2904 & 187957 & 238552 \\
\hline & 2031 & - & 8544 & 1369 & 10598 & 7477 & 2904 & 170830 & 201722 \\
\hline
\end{tabular}

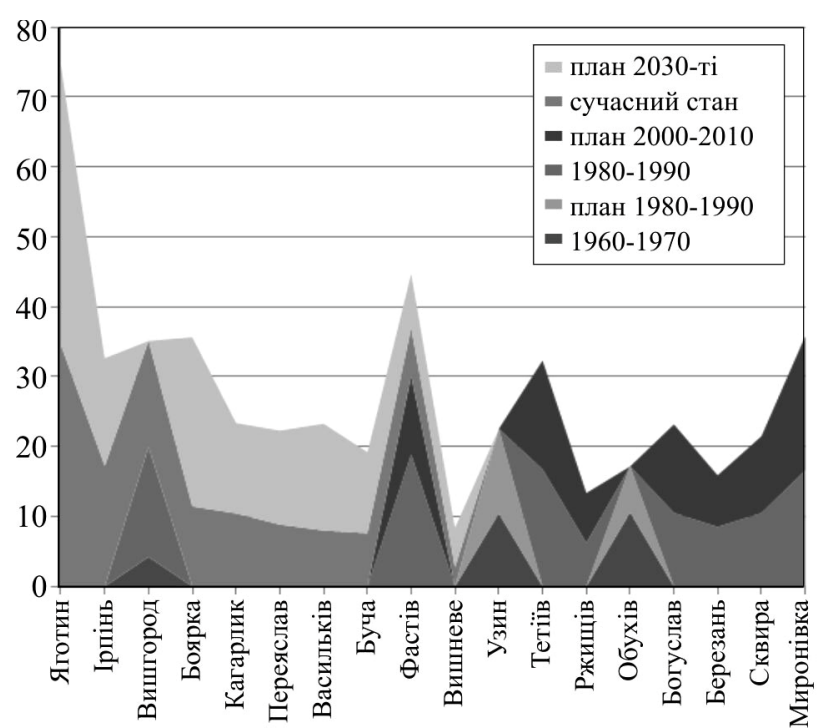

Рис. 3. Динаміка вартості екосистемних послуг на 1 га площі малих міст за даними генеральних планів міст (міста подали в порядку зниження показника сучасної вартісної оцінки)

Погіршення показника у перспективі виявили у плані м. Обухів, що пов'язане із запланованим кардинальним ривком у його розвитку, а також міст Фастова, Березані, Тетієва і Вишгорода, що можна віднести до низької якості планувальних робіт. Аналогічну ситуацію простежуємо за новим генеральним планом Ірпеня. У разі відстеження динаміки потенційного надання екосистемних послуг під час планування такого негативного явища можна було б уникнути.

Висновки. Відстеження динаміки вартісного оцінювання одержуваних на території малих міст екосистемних послуг дає змогу оцінювати екологічну стабільність розвитку міської території.

Встановлено, що зростання площі відбувалося у $72 \%$ малих міст із розширюванням їх забудови. Найвищим рівнем забудови характеризуються міста Вишневе, Переяслав, Васильків, Фастів, а найменшим - Кагарлик і Яготин. Значна частка у загальній площі міських біотопів належить присадибним садам, питома вага яких змінюється в межах від 4 до 30 \%. Орні землі представ- лені вкрай нерівномірно і в деяких містах відсутні, хоча їхня частка в окремих містах сягала 80 \%, а в перспективних планах - 50 \%. Ліси відсутні на території третини дослідних міст. Площа водних поверхонь найістотніше позначається на вартості біотопів, характеризується нерівномірним розподілом і іï частка сягає 30 \%. Здебільшого присадибні сади займають найбільшу питому вагу в загальній вартості міських біотопів. В окремих випадках їм належить до $85 \%$ вартості. Найбільший відсоток лісів у загальній вартості відзначено для міст Ржищів, Вишгород, Ірпінь, а водойм для Яготина, Тетієва, Миронівки, Богуслава, Кагарлика. Ці показники важливо враховувати у перспективних планах розвитку міст, де для обгрунтування нормативної площі зелених просторів потрібно брати не тільки рекреаційні норми зелених насаджень загального користування, а сукупність екосистемних послуг багатофункціональних зелених територій, які гарантуватимуть екозбалансований розвиток територій.

\section{Перелік використаних джерел}

Arnold, J., Kleemann, J., \& Fuerst, C. (2018). A Differentiated Spatial Assessment of Urban Ecosystem Services Based on Land Use Data in Halle, Germany. Land, 7(3), 101. https://doi.org/10.3390/land7030101

Artmann, M., Bastian, O., \& Grunewald, K. (2017). Using the Concepts of Green Infrastructure and Ecosystem Services to Specify Leitbilder for Compact and Green Cities - The Example of the Landscape Plan of Dresden (Germany). Sustainability, 9(2), 1-27. https://doi.org/10.3390/su9020198

Bastian, O., Grunewald, K., \& Khoroshev, A. (2015). The significance of geosystem and landscape concepts for the assessment of ecosystem services: exemplified in a case study in Russia. Landscape ecology, 30(7), 1145-1164. https://doi.org/10.1007/s10980-0150200-x

Bastian, O., Haase, D., \& Grunewald, K. (2012). Ecosystem properties, potentials and services - The EPPS conceptual framework and an urban application example. Ecological Indicators, 21, 7-16. https://doi.org/10.1016/j.ecolind.2011.03.014

Choe, H., \& Thorne, J. H. (2019). Omnidirectional connectivity of urban open spaces provides context for local government redevelopment plans. Landscape and Ecological Engineering, 15(3), 245251. https://doi.org/10.1007/s11355-019-00377-8 
Gómez-Baggethun, E., \& Barton, D. (2013). Classifying and valuing ecosystem services for urban planning. Ecological Economics, 86, 235-245. https://doi.org/10.1016/j.ecolecon.2012.08.019

Groot, R., Wilson, M., \& Boumans, R. (2002). A typology for the classification, description and valuation of ecosystem functions, goods and services. Ecological Economics, 41(3), 393-408. https://doi.org/10.1016/S0921-8009(02)00089-7

Grunewald, K., Bastian, O., \& Schweppe-Kraft, B. (2014). Das Konzept der Ökosystemdienstleistungen. In Erfassung und Bewertung Erfahrungen, insbesondere aus Deutschland und Russland. (pp. 13-36). Bundesamt für Naturschutz. Retrieved from: http://www.kulunda.eu/sites/default/files/BfN Skript 373.pdf

Lam, S. T., \& Conway, T. M. (2018). Ecosystem services in urban land use planning policies: A case study of Ontario municipalities. Land use policy, 77, 641-651. https://doi.org/10.1016/j.landusepol.2018.06.020

May, A., \& Spirin, P. (2014). Berücksichtigung ökologischer Belange in der Territorialplanung der Russischen Föderation. In Erfassung und Bewertung von Ökosystemdienstleistungen (ÖSD) - Erfahrungen, insbesondere aus Deutschland und Russland Bonn. (pp. 320339). Bundesamt für Naturschutz.

Olic, P., \& Stober. D. (2019). Urban Green Infrastructure for Shrinking City: Case Study - City of Osijek. IOP Conference Series:

Materials Science and Engineering, 471, 102025. https://doi.org/10.1088/1757- 899X/471/10/102025

Schweppe-Kraft, B. (2014). Ökonomische Bewertung sverfahren in der Praxis. In Erfassung und Bewertung. (pp. 148-357). Bundesamt für Naturschutz. Retrieved from: http://www.kulunda.eu/sites/default/files/BfN Skript 373.pdf

Semenov, Ju. (2014). Nutzungsmöglichkeiten der Landschaftsplanung bei der Herausbildung eines Marktes für Ökosystemdienstleistungen. In Erfassung und Bewertung von Ökosystemdienstleistungen. (pp. 350-357). Bundesamt für Naturschutz. Retrieved from: http://www.kulunda.eu/sites/default/files/BfN Skript 373.pdf

Wang, Y., Li, X. M., Zhang, Q., Li, J. F., \& Zhou, X. W. (2018). Projections of future land use changes: Multiple scenarios-based impacts analysis on ecosystem services for Wuhan city. Ecological Indicators, 94(1), 430-445. China. https://doi.org/10.1016/j.ecolind.2018.06.047

Xu, Q. R., Zheng, X. Q., \& Zheng, M. R. (2019). Do urban planning policies meet sustainable urbanization goals? A scenario-based study in Beijing, China. Science of the total environment, 670, 498507. https://doi.org/10.1016/j.scitotenv

Yukhnovskyi, V. Yu., \& Zibtseva, O. V. (2019). Assessment of ecosystem services in the general planning of urban areas. Naukovi pratsi LANU, 18, 185-193. https://doi.org/10.15421/411919

o. V. Zibtseva, V. Yu. Yukhnovskyi

National University of Life and Environmental Sciences of Ukraine, Kyiv, Ukraine

\section{THE RESTORATION COST OF THE ECOSYSTEMS OF SMALL TOWNS} OF KYIV REGION AS AN INDEX OF ECO-BALANCE

The purpose of the study is to analyze the dynamics of the structure of the territories of small towns of Kyiv region and to determine the eco-balance of the territories by comparative analysis of the towns by the cost of restoration of their ecosystems. The object of the study is the most widespread category of Ukrainian towns - small towns (with a population of 10 to 50 thousand inhabitants) of Kyiv Region, which accounts for $80 \%$ of the total number of cities. It is found that the population in small towns of the region is significantly negatively correlated with the distance to Kyiv, in the area of influence of which these towns are located. For 20 towns in the region, there is a significant correlation between these indicators. The analysis of the territorial structure was carried out on the basis of the main indicators of the existing master plans of small towns. The cost of eco-stabilizing biotopes per 1 ha of urban area is calculated for the previous state of each town and for a 20 -year perspective. It is found that $72 \%$ of small towns were increasing with the expansion of their development. The highest levels of development are characterized by the towns of Vyshneve, Pereyaslav, Vasylkiv, Fastiv, and the smallest - Kagarlyk and Yagotyn. Considerable share of the total area of urban biotopes belongs to private gardens, which share varies from 4 to $30 \%$. Arable land is represented very unevenly and in some towns is absent, although their share in some towns reached $80 \%$ and in the perspective plans $-50 \%$. There are no forests in the territory of one third of the experimental cities. The area of water surfaces has the most significant influence on the value of biotopes, and is characterized by uneven distribution and its share reaches $30 \%$. In most cases, gardens are the largest share in the total cost of urban biotopes. In some cases, they account for up to $85 \%$ of the cost. The largest percentage of forests in the total value is determined for the towns of Rzhyshchiv, Vyshgorod, Irpin, and reservoirs - for Yagotyn, Tetiev, Myronivka, Boguslav, Kagarlyk. These indicators are important to take into account in future urban development plans, where not only recreational norms of green spaces for public use, but also a set of ecosystem services of multifunctional green territories, which will guarantee eco-balanced development of territories, must be taken into consideration to justify the normative area of green spaces.

Keywords: ecosystem services; green space; biotope; city master plan. 